Revue de l'Institut des langues et cultures

d'Europe, Amérique, Afrique, Asie et Australie

39 | 2020

Les humanités numériques dans une perspective internationale : opportunités, défis, outils et méthodes

\title{
Mobile Mapping and its Potential for Faculty Collaboration and Undergraduate Student Learning
}

La cartographie mobile et son potentiel pour la collaboration entre professeurs et l'apprentissage des étudiants de premier cycle

Christopher J. Young, Joseph A. Ferrandino and Faedah M. Totah

\section{OpenEdition}

\section{Journals}

Electronic version

URL: http://journals.openedition.org/ilcea/8792

DOI: 10.4000/ilcea.8792

ISSN: 2101-0609

Publisher

UGA Éditions/Université Grenoble Alpes

Printed version

ISBN: 978-2-37747-174-4

ISSN: $1639-6073$

Electronic reference

Christopher J. Young, Joseph A. Ferrandino and Faedah M. Totah, « Mobile Mapping and its Potential for Faculty Collaboration and Undergraduate Student Learning », ILCEA [Online], 39 | 2020, Online since 03 March 2020, connection on 10 October 2020. URL : http://journals.openedition.org/ilcea/8792 : DOI : https://doi.org/10.4000/ilcea.8792

This text was automatically generated on 10 October 2020

(C) ILCEA 


\section{Mobile Mapping and its Potential for Faculty Collaboration and Undergraduate Student Learning}

La cartographie mobile et son potentiel pour la collaboration entre professeurs et l'apprentissage des étudiants de premier cycle

Christopher J. Young, Joseph A. Ferrandino and Faedah M. Totah

\section{Introduction}

1 Undergraduate research is a high impact practice for student learning, but the key is often to match projects with tools that build students' skills as they learn about a topic. Digital tools now profligate to the point that they are almost overwhelming to the student and instructor alike. These tools, coupled with computing have forged an entirely new field: digital humanities. There has been an increase in how digital humanities impact scholarship and research especially with new technological innovations that allow for new ways of collecting, analyzing, and presenting data. However, with the focus on research, there has been less work or interest on the role of digital humanities in pedagogy (Brier, 2012; Waltzer, 2012; Hirsch, 2014; Thomas \& Solomon, 2014; Young, 2018). Therefore, the potential for digital humanities largely remains neglected in pedagogy especially when it comes to undergraduate teaching and learning (Brier, 2012: 390). Nonetheless and as Brier has noted, digital humanities offer not only new ways for stimulating and enhancing student learning, but equip students, both undergraduate and graduate, with skills and resources needed for their future employment (2012: 390). There are many ways to use digital humanities in the classroom and case studies on its application are a great way to demonstrate its range in student learning. In this essay, we try to demonstrate the ways in which the digital humanities can offer new ways of teaching that engage students at the undergraduate level. We also offer an example for collaboration among faculty in different disciplines and at different institutions that is made possible by the use of new digital technology 
and tools. Below we discuss how one easy to use, student friendly digital tool-ArcGIS's mobile app, Collector-has the potential to be used in collaborative undergraduate research. The tool's usefulness stems from its potential to contribute to the understanding of pedagogy and digital humanities with its actual practice in the classroom.

\section{Using GIS as a Learning Tool: A Brief Background}

2 Teaching through GIS (geographical information systems) is neither unique nor innovative in and of itself. Scholars across the academy have either called for, or detailed their experiences, teaching with GIS, including, but not limited to the fields of criminal justice (Ferrandino, 2015; Althausen \& Mieczkowski, 2001), public affairs (Ferrandino, 2014; Mason, 2008), social work (Coulton, 2005; Hillier, 2007; Queralt \& Witte, 1998; Weir \& Robinson, 1998), urban planning (Yin, 2010), history (Young \& Ferrandino, 2018; Snyder \& Hammond, 2012; Sinton \& Lund, 2006), agriculture, environmental sciences, geology (see Fagin \& Wikle, 2011), business (Shepherd, 2009) and even Portuguese literature (Alves \& Queiroz, 2015). Sinton (2009) makes an impassioned case for the benefits of teaching with GIS across higher education as its use can achieve such goals as "critical and creative thinking, quantitative literacy, information literacy, civic responsibility and engagement and intercultural knowledge...through pedagogical formats such as problem-based and active learning, undergraduate research, first-year seminars, interdisciplinary courses and senior capstone courses, or even general education courses" (p.S8). Clearly, there is widespread support for teaching with GIS at all levels of education.

What is unique and valuable, however, is how GIS is utilized in teaching in different disciplines. One example is the use of existing GIS systems and maps to teach high school students about genocide (Fitchett \& Good, 2012) and the world about the holocaust (see Knowles, 2008). Others have taught GIS through problem-based learning and action research projects within their communities. One project mapped food insecurity in Syracuse, New York (Read, 2010) while another analyzed a proposal to add another school district in San Antonio, Texas (Drennon, 2005) and a third that worked with non-profits in two Chicago, Illinois, neighborhoods to build a GIS database (Wood, 2009). In a criminal justice course, Ferrandino (2015) showed how combining existing census data, open city data and the publicly available Stop, Question and Frisk databases into one GIS file could be used to teach about policing, corrections, sociology, race, criminology and diversity. These examples, while not exhaustive, illustrate how GIS and mapping can be used to teach a variety of disciplines. The importance of this endeavor cannot be understated as a National Geographic survey found that $11 \%$ of young Americans could not find the United States on a map; $29 \%$ could not locate the Pacific Ocean; 58\% could not locate Japan; $65 \%$ could not locate France; $69 \%$ could not locate Great Britain, and over $80 \%$ could not locate Iraq, Afghanistan or Israel-and this was over fifteen years ago (Trivedi, 2002). If the purpose of higher education in the United States is to create a well-informed citizenry, then students should be able to envision the map of the world and the impact of their political choices on other peoples living in other places.

4 In this case study, we offer an example for using the digital Collector App in courses offered at Indiana University Northwest by Christopher Young and Joseph Ferrandino. 
The two instructors collaborated with Faedah M. Totah at Virginia Commonwealth University. Young and Ferrandino first realized the potential of the Collector App while at the Digitorium Symposium at the University of Alabama. There they located a monument in front of the library that described the burning of the university by Union troops during the American Civil War. They opened up the Collector on one of their phones, entered the information from the monument, and uploaded the photo. Soon afterward, at the start of their workshop on their GIS activities, they shared it with those present at the session by projecting the results onto a screen. Apparently, they were the only people in the room unfamiliar with the story! Nonetheless, the experience gave them an idea for future class projects and where the city of Gary, Indiana, and the surrounding area could be used as laboratory for learning more about American history from the monuments, statues, and plaques that exist in the region.

\section{An Overview of the Tool Itself}

5 Students come to the classroom with a wide array of digital tools that they use in their daily lives to stay connected to their social network and engage in the world around them. For instance, it is rare to find a student in American universities and colleges who does not have a smartphone with different apps and streaming services. The aim of our work is to harness the digital skills and tools students already have to make the learning experience inside the classroom more relevant to their lives outside of the classroom. This requires new ways to approach teaching and learning that take into account the digital humanities in curricula and course development (Ives, 2014). Moreover, digital humanities allow and encourage new ways of collaboration inside the classroom and beyond (Iantorno, 2014; Gossard, 2017). While digital tools are readily available, finding ways to incorporate them effectively into the curriculum can be perplexing especially as many faculty do not regularly use these tools in their own scholarship. Since, faculty are unfamiliar with the potential and many applications of these tools, they feel hesitant to incorporate them in courses. Moreover, some disciplines and courses lend themselves more easily to digital tools than others. For instance, academic fields that make use of mapping typically incorporate GIS and other similar digital tools in the curriculum. Therefore, case studies on the use and application of digital tools in and across disciplines and courses are one way to provide faculty with ideas for their own classes. Assignments using digital tools should serve a learning objective connected to the course material and not seem to be randomly selected to give students work to do. Therefore, it is important to include the trials and errors in case studies on the use of digital tools to allow other faculty contemplating their use to see how these tools can be tailored to fit the pedagogical goals and demands of the course. In addition, there is the issue of access to these tools. While many apps and programs are free and readily available online, and can easily be downloaded, these easy to access tools have restrictions on their usage that limit what they can be used for in the classroom and for how long. Having funding or university resources to purchase digital tools is important for faculty interested in the long-term benefit of the use of such tools in their courses. Along the same lines is the ability of institutions to provide technical support for faculty who need training in their application or access to tech support to help with problems that might arise when using these tools by both students and faculty. Hence, this case study offers one example of not only applying digital humanities in the classroom but also of an 
opportunity for collaboration between faculty and students at different institutions and with different resources. It demonstrates how faculty can start using digital tools in a limited capacity but still see the impact on student learning. While the scope of the collaboration was also limited and was not planned before the beginning of the semester in which it was conducted, the experience was important for the many lessons learned regarding the use of digital tools and for planning and implementing future collaboration.

6 The Collector App for ArcGIS is a mobile app for smart phones that allows students to make direct entries into a map. That is, it allows students to collect information at the physical location. It encourages undergraduate students to go beyond the confines of the classroom and into the field to conduct research with one of their favorite tools, their smartphone. It enhances their learning as it allows them to interact with course material in a new way. It encourages them to see how history is around them in the monuments, statues, and plaques that exist in their surroundings and to which they tend to be oblivious. The Collector App also allows past-present-and future classes of students to intermingle in a digital space that is devoted to creating knowledge for public use. The easy-to-use digital tool facilitates undergraduates in the Humanities and other disciplines to become cognizant of the world immediately around them in a new way while also equipping them with a technical skill that may be applied in other courses as well as in future employment scenarios. In short, the Collector App serves as a place where applied research and the scholarship of discovery intersect. As such, the Collector App contributes to the expansion of the digital humanities into undergraduate education. However, it should be clear that the use of digital tools is not for the sake of incorporating technology in the classroom, but to employ new tools in enhancing undergraduate education. At the same time, we seek ways to encourage collaboration made possible by these tools. We present as evidence collaborative digital undergraduate projects that span classes, semesters, and universities. All involve primary field research through Collector. The Collector-based research projects encourage students to build skills while contributing to knowledge in new ways. As professors, we find ourselves learning from the student research as a result of their mapping history.

7 Maps and the stories they tell invite interdisciplinary collaboration. In this particular case, history and, anthropology. As we have progressed in our collaboration, so have our students. Students began by collaborating with one another in class. Now they are able collaborate across semesters, and more recently across regions and universities within the United States. In the following pages, Christopher Young and Joseph Ferrandino will discuss the use of a Mobile Mapping Application as it was carried out while both were at Indiana University Northwest and Faedah M. Totah will describe how she and her students used the same app in one of her courses at Virginia Commonwealth University.

8 Working together for six semesters as a multidisciplinary collaborative effort, Young and Ferrandino have designed several Geographic Information System (GIS)-based projects to help students achieve the following learning objectives: Learning American history within the context of geography; learning how to use GIS more broadly, including spatial relationships, to learn about the connections between history and geography; and learning about American history through collaborative mapping projects at the class, group, and individual levels. 
9 By plotting the movements of historical figures such as Abraham Lincoln or the locations of assigned primary documents for a course devoted to Colonial and Revolutionary America, digital mapping invites students to see how historical events and places that may seemingly exist only in the imagination, actually did and do exist in places within our modern world. The life of the mind becomes visual for students when they plot what they are studying. Based off students' feedback on these early GIS projects, Young and Ferrandino utilized the ArcGIS Collector app in an introductory early American history course at Indiana University Northwest to introduce students to a new technology, to increase their awareness of the monuments, markers, and memorials. As an experiment for collaboration with students at another institution, Young and Ferrandino reached out to Totah in Spring 2018 at Virginia Commonwealth University who was able to revise an assignment in her existing course to suit the purposes of the ongoing class project at Indiana University Northwest.

The ArcGIS Collector app encourages undergraduate students to engage in research for academic and practical applications. The ArcGIS Map Collector is a product of ESRI and is available for free download on any mobile device. However, for such a project, there is a suite of three products required. First, the underlying layers and map have to be created in ArcGIS Desktop, a product that is standalone and does not allow for collaboration between users. To collaborate, the map is uploaded to a shareable format on ArcGIS Online, for which a subscription is needed. In this format, students can collaborate within the same map (add, edit or delete data) from different locations. The mobile app, the third software in the suite, is free, connects to the online map but allows students the freedom and mobility to collect information in the field that updates in the map. This last tool was perfect for students viewing monuments and statues and adding the picture and its information directly into the same map being used by other students.

11 We begin with a description of the class project in Gary, Indiana and then in Richmond, Virginia. We offer some observations on the collaboration between the two institutions and recommendations for future collaborations.

\section{Gary, Indiana, USA}

Over the last several years, Young and Ferrandino have used ArcGIS for both individual and group projects. Beginning in the Fall 2017 semester they offered the Collector App to an introductory early American History course. Students in this course are generally first year college students with limited exposure to learning technologies beyond what is considered the norm in American high schools. The campus is located in Gary, Indiana, a town founded in 1906, and serves a student body that is made up mainly of first-generation students, those who are the first in their families to attend college. While some of the towns in the immediate region called Northwest Indiana originate as far back as the 1840s, the area is not rich in documented early history that is readily connected to local or national narratives. The American Civil War era would probably be, generally speaking, the earliest place to start any research on monuments, but that is also the event that closes out the course. Consequently, the challenge faced by the instructors was to include an assignment that would invite mapping of early American subjects, but also allow them to create an assignment that would encourage students to walk around and "collect" the history in their midst. Ultimately, students were engaged 
in a crowdsourcing project centered on "participatory knowledge" (Heppler \& Wolfenstein, 2015).

The instructors decided to use the Collector App as a way to introduce students to monuments as well as to the ArcGIS technology. The assignment was fairly straight forward: find a monument in the area and plot it onto the map using the Collector App while also adding information to the point on the map for the benefit of others. After explaining to students the steps involved in using the App, they were on their way! The most obvious monuments were plotted first. The students who procrastinated were forced to dig a little deeper and to broaden their search. A few weeks later the instructors asked students to repeat the task. And again, students were forced to search more conscientiously. The instructors encouraged students to ask parents, friends, and neighbors if they knew of any monuments. When Young and Ferrandino extended this same assignment into a second semester, the students found it even more challenging to find additional monuments to map. Yet, they continued to encourage students to strive to find more since they were aware of the existence of monuments that had not yet been identified and plotted by students in the previous class.

Once a student located a monument in their neighborhood, they would click on the Plus symbol (+). This takes the user to a page that asks for information regarding the monument and includes: Statue/Monument Title, Location, Broader Significance of the Monument, Date Monument Placed or Created, Date Student Entered Their Work in a Map, Student Name, Type of Person Honored (e.g. Entertainer, Athlete, Soldier). The student can also click on the camera icon and add a photo to the entry. To finish with the data entry, they click Done. The instructors recommend that students take a photo first before entering the information in order to avoid minimizing and maximizing sites on their mobile device.

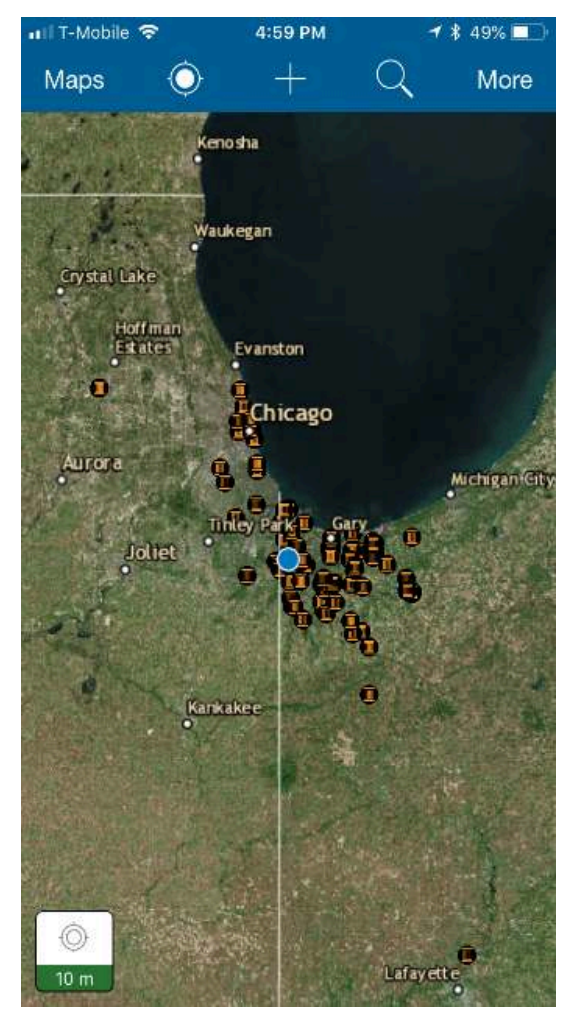

Screenshot of the Collector Application on a mobile device. The first part of the project required students to identify monuments in northwest Indiana and nearby areas. 


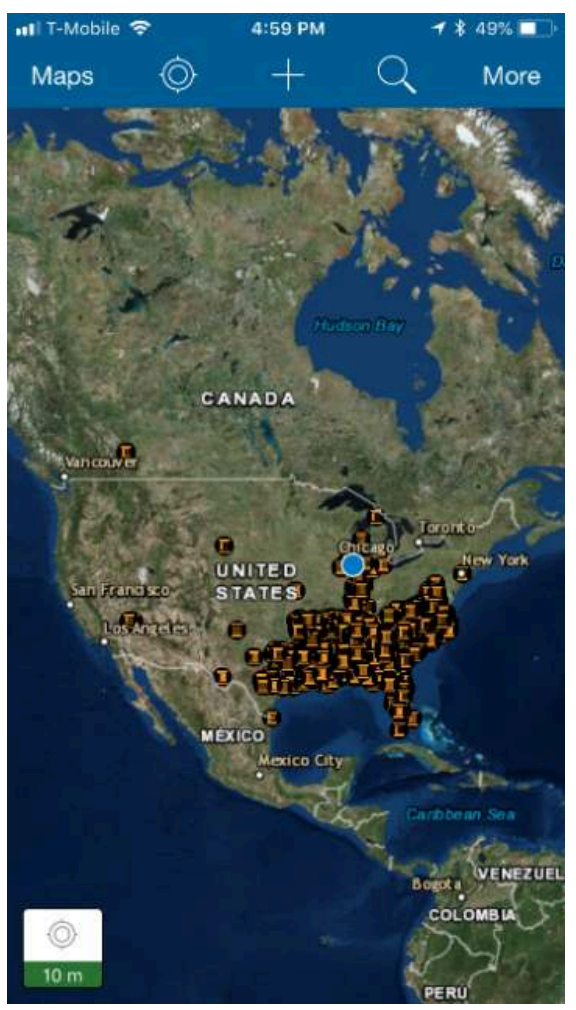

Screenshot of the Collector Application on a mobile device. Later in the semester students were asked to broaden their search for monuments, in particular Civil War and slavery-related monuments. Additionally, students were encouraged to use the Collector App to document monuments that they came across while traveling even if they were unrelated to class. Our objective was to build students awareness that monuments and memorials are ubiquitous and that they are intended to convey a message about the past to the ongoing present of those who stand before the monument or memorial at a given moment.

The Collector App mapped the monuments in Northwest Indiana, which included more generally, the Chicagoland area over the course of two semesters of an introductory early American History class. The focus was on documenting monuments in the area referred by locals as The Region. As monuments in the area became increasingly more difficult to find, some students began to plot in Chicago and the surrounding suburbs. This may also have been the result of where a student lived, worked, and played. And as students reported in the surveys administered toward the end of the semester, one of the aspects they liked most about the Collector is that it was on their phone, and their phone goes everywhere with them. Consequently, they can plot on the go. This in turn permitted students to learn beyond the classroom, even after the semester ended, such as mapping monuments and markers as they traveled for work or on family vacation. As a result, the instructors ended up with points all over the United States and Canada as students and professors found interesting statues and monuments everywhere they went.

The project that expanded two semesters was essentially a collaboration between two sections of the introductory early American History course. During the second semester of the project, Young and Ferrandino began to collaborate with a colleague at another university in a different region of the United States. This is where Faedah M. Totah and her students at Virginia Commonwealth University in Richmond Virginia came into the project. The course she taught was not an early American History survey course and her students did not include freshmen. Nonetheless, it included a session on 
monuments and memorial in Richmond and that was seen as sufficient for a limited collaboration to take place. However, and since the collaboration started after the semester had begun, the course was not designed with the same objectives and aims as the American History Survey course. Nonetheless, it offered an unique opportunity to include an assignment using the Collector App. Students at Indiana University Northwest were exposed to monuments in another part of the country.

\section{Richmond, Virginia, USA}

At Virginia Commonwealth University (VCU) the course was a new offering designed to introduce students to issues of social justice and the city. The course was offered in the International Studies program and focused largely on the anthropology of the city. It was designed to encourage students to explore Richmond and to document inequality and uneven development in the city through ethnographic research. Most of VCU students are not from Richmond and the course was designed with the aim of getting students to know the city beyond the neighborhoods where they lived, studied, and worked. Hence and although the courses were not initially designed for collaboration and were in different disciplines and targeting undergraduate students at different levels, they both included segments on knowing the city and recognizing the different monuments in the cityscape. Moreover, both courses involved some form of mapping and while students at Indiana University Northwest had access to the Collector App and ArcGIS, the students at VCU had an in-house version of a program that performed a similar task. These common denominator between the two courses was enough for collaboration to take place.

It was several weeks into the semester when the instructors from Indiana University Northwest contacted the faculty member at VCU and suggested to include VCU students in the mapping exercise using the Collector App and ArcGIS. The instructors were interested in comparing monuments in two cities. The purpose was for students in Indiana to see the different types of monuments and memorials in other regionsand this object was achieved. The preponderance of Confederate and Civil War monuments in Richmond as compared to Gary attests to the historic role the city played in the conflict. There was no hesitation in agreeing as it required altering the assignment slightly, but the students still had to discover the different monuments and memorials in the city. It was also a good opportunity to demonstrate how different disciplines, in this case history and anthropology, were involved in the same teaching activities, but with different learning objectives. Whereas the American History Survey course was geared toward encouraging learning of history through the monuments in the city and surrounding area, the social justice course was designed to have students recognize the inequalities that exist in the city. These inequalities are mapped onto the city and in the social practices of remembering and forgetting as whose history is remembered and recorded in monuments and statues and whose is forgotten.

In order to enhance student learning the instructor at Virginian Commonwealth University worked closely with the university's Academic Learning Transformation Lab (Alt-Lab) to design a website for the course where students could map and post their assignments. Alt-Lab created a course website that included a map of Richmond that allowed students to post their assignments directly on the map. Students could access the website from their Smartphones when they were out in the city and map their 
location, but they could also collect the data and enter it at a later time. The instructor wanted to experiment with digital assignments as a new way for students to be evaluated. The assignments were constructed in a way that required students to visit different neighborhoods and to map what they discovered on the course website. However, the course was also designed using tools and resources made available to faculty at VCU. This meant that the digital tools used in the course were the ones that were readily available to faculty at VCU but that also facilitated the work of the students in documenting the parts of the city they were exploring. These tools also allowed students to see the data plotted on a map. In some ways the website created for the course served the same purpose as the Collector App and the ArcGIS which was not available for the faculty to use at VCU due to lack of funding.

One of the assignments designed for the course involved mapping monuments in Richmond. This is where the two courses overlapped and allowed for the collaboration to take place. The assignment for students at VCU was somehow different as they required students to find a monument or memorial in Richmond, map it on the course website, and then research its history and significance in the city. They then wrote a short essay that they linked to the image of the monument on the website. The assignment was designed to encourage students to see how memory and history are political matters that are transcribed on the cityscape. Richmond is rich in historical sites spanning the early days of British settlement through the Revolutionary and Civil Wars. As the capital of the Confederacy during the Civil War it had several sites and monuments dedicated to the southern cause. Therefore, students had numerous sites to choose from throughout the city. As most of the students were not from Richmond and were unfamiliar with some of the neighborhoods or uncomfortable exploring on their own, the instructor pointed out certain neighborhoods and parks where monuments were present. The assignment was quickly and easily modified to use the Collector App and to map the monuments on ArcGIS instead of the course website. The essay was no longer a requirement, instead students had to find and map at least five monuments.

21 Unlike with the course at Indiana University Northwest, the instructor took students on a tour of the VCU campus to show them the different commemoration techniques. On or near VCU campus there are several sites of commemoration for the Civil War, Suffragettes in Richmond, and sites of buildings important to VCU history. There is also a memorial for the Holocaust on the grounds of the Catholic Cathedral next to VCU. This tour enhanced the mapping part of the assignment as it allowed students to appreciate the diversity in urban memorialization but also how easy it is to overlook these historic markers. Examples of commemoration included plaques in front of buildings, which students passed numerous times, but did not notice much less stop and read the inscriptions. Statues were more familiar to students, but none had stopped to read the inscription. This field trip proved important in helping students notice the city around them, but also to prepare them for the assignment that required them to research these acts of memory beyond campus.

It should be noted that the instructor at VCU was not familiar with neither the Collector App nor ArcGIS, but from the conversations and emails with Young and Ferrandino, it became clear that this lack of knowledge was not an issue. As a matter of fact, it allowed the instructor to learn about the mapping tool and its pedagogical potential. Collaborating with instructions at Indiana University Northwest did not 
require additional effort from VCU students other than downloading the Collector App to map five unique memorials and monuments onto ArcGIS. Moreover, and since mapping was already included in the course, revising the initial assignment to using the Collector App was straightforward and students were willing to try another tool for mapping monuments in Richmond. It also offered them the opportunity to compare between the VCU mapping program designed for the course and the Collector App.

While the instructions to use ArcGIS were clear, it became apparent that the use of Smartphones poses its own unique challenges. While all the students in the class had a Smartphone and agreed to use them for the course assignment, there were variations between iPhones and Androids. Moreover, depending on the age of the phone and how much memory it had, some students had difficulty downloading the App. This led students to problem solve and to help each other with technical issues as well as with downloading the App. This peer-to-peer collaboration offered students another opportunity to get to know and learn from one another. However, after the initial technical issues, the students were on their way mapping monuments in Richmond. Since they had been using the website designed by Alt-Lab for other assignments, they quickly noted the differences in using the Collector App.

The VCU students loved using the Collector app and preferred it to the website designed by ALT-Lab. Once the App was downloaded on their smartphone it was easier to use and the students could immediately see their site mapped on the website. The course website in comparison to the ArcGIS was cumbersome especially when the Wi-Fi signal or cell coverage was weak. If they could not enter their data on the website when they were on site, they gathered the coordinates and entered the information on their computer when they got home. Having an App was more convenient and easier to manipulate. It also made the assignment more enjoyable. Moreover, this collaboration demonstrated to the students the "gap" between what digital tools they had and what was available at other institutions, therefore encouraging them to think of limits when it comes to technology and its place in their learning (Ives, 2014: 223). Collaborating with the faculty at Indiana University Northwest allowed the students at VCU to learn about new digital tools that gave them a different perspective on the assignment and the role of technology in teaching and learning. They also were aware of other tools to facilitate mapping if they need to do a similar project in the future.

Although the collaboration between Indiana University Northwest and Virginia Commonwealth University was limited in scope and scale, it did offer one example of how partnerships between faculty at different institutions could take place. Sharing of resources between different institutions, when possible, is a good way to encourage participation of faculty and students in digital humanities projects. In this case study the collaboration between faculty was also limited as it happened after the course began, which meant it was not incorporated in the course design. Moreover, it was a collaboration between two different courses in different disciplines. Therefore, students were not involved in the planning of the course and the results of this collaboration remain restricted to one assignment. While the students at Indiana University Northwest had access to the mapping of monuments at VCU, the students at VCU were not privy to what the students in Indiana were doing. Hence, student involvement in the collaboration was also limited.

Nonetheless, as a first-time collaboration with another faculty member and at a different institution, it went well especially since it the instructor at VCU was not 
familiar with use of ArcGIS in courses. Nonetheless, it offered a way for faculty to work together using digital humanities as a means of improving student learning. It also highlighted the need for more planning that would involve students at the two institutions for the collaboration to be more effective. It would be interesting in the future to have a deeper collaboration in which students at both universities are more involved in planning the course and coordinating the assignments over the span of the semester. The digital tools, including mapping technologies, allow for different forms of relationships to develop and it remains to see which tools are best suited for bringing both faculty and students together.

One aspect of this limited collaboration that remains important to note is that students at VCU, were exposed to another digital tool and a new assignment. They quickly mastered the Collector App and were able to see the limitations of the tool they were using and that was designed by VCU. It also allowed them to see the concentration of monuments and memorials in Richmond plotted on a Google map that they are more familiar with and that is different from the map on the course website. In the process of doing the assignment, they had an opportunity to know the city in which they live, work, and study a little better. They also saw the potential of the Collector App and ArcGIS for future projects and assignments. The students also appreciated the departure from research papers and written assignments, but this did not affect their learning. By being out in the city, using digital tools, mapping, and analyzing the data, they were able to learn by doing research.

\section{Becoming Aware}

The different aims and objectives of the courses, student backgrounds, and limited scope of collaboration make it difficult to draw general conclusions from the partnership between Indiana University Northwest and Virginia Commonwealth University. However, is easier to assess the impact of using digital tools on students' learning. Toward the end of each semester, the students were asked to fill out a survey that included seven questions (The survey provided to students at Virginia Commonwealth University included two more questions.) The survey indicates that students believed using the Collector App facilitated their learning. Over the course of two semesters, $64.29 \%$ to $79.17 \%$ reported that they believed that using the app contributed to their learning. The VCU courses included nine students and only three answered the survey. The three who answered the survey, or $1 / 3$ of the class, unanimously agreed that the collector app contributed to their learning.

How students perceived what is learning was similar at both Indiana University Northwest and Virginia Commonwealth University. For the students at both institutions, learning equated to awareness. Awareness seemed to be the main theme 
when students were asked to explain their answer regarding learning. Sampling of these responses include:

- "I enjoyed using the collector app. It definitely made me aware of the monuments and markers that I pass daily."

- "I learned to be more aware of the monuments in my area and the significance of them."

- "The assignment made me aware of the various markers and monuments around us that go unnoticed on a daily basis."

- "helped me learn a little more about my town."

- "it opened my eyes to the things I never noticed around me before."

- I didn't know there were so many monuments around my location."

- "It made me more aware of the monuments around me and the history that was memorialized."

- "It puts how a city chooses to remember its history into perspective. For example, where certain monuments are in relation to others and to the people living in proximity to them."

\section{A} could then have it in their technological toolbox to be used in other classes or in their early careers, a key benefit of encouraging students to experiment with the assortment of digital tools at our disposal (Gossard, 2017) We were hopeful because in earlier classes some students found that the ArcGIS platform and the skills developed through the mapping projects were transferrable. In one upper division course, a student found that she could imagine using ArcGIS in her banking position to identify areas mostly likely to apply and receive loans. Another student said that he may try to incorporate it into the work he was already in doing in the health field. In this instance the student was thinking about his/her desire to pursue a career in the health field and how ArcGIS could be used to map clinics and hospitals in neighborhoods or cities. This type of mapping tool can be useful in understanding the health needs of populations. Equipped with information from an earlier course, we hoped that the Collector App would strike students as being equally utilitarian. 

instance, one student said that the Collector App "gave me another tool to add to my list of competencies" while another student stated that it "allowed me to understand this new technology and how to share important information that others can view."

\section{Conclusion}

The ArcGIS Collector App empowers students to learn on the move by quite literally putting the vehicle for that learning into their hands by utilizing their mobile devices. As such, learning moves beyond the classroom, and by doing so, contributes to the understanding that the intellectual endeavor is not confined to a particular time or place. To underscore this reality, the Collector App invites the opportunity to collaborate with others across disciplines, semesters, regions, and universities. Sharing research with others introduces students to the world of scholarly collaboration and the scholarship of discovery. In the process, as it relates to our work on monuments in two different courses and cities, students gain a greater awareness of their neighborhoods as well as those of others. This is consistent with the use of GIS across and between fields and disciplines ranging from business to history and from criminal justice to environmental studies. In other words, it can be used for student learning in any field as all have some geospatial element and the software, once learned, can be applied by students in their current or future careers.

This case study demonstrates how digital humanities can encourage both learning and collaboration through creating new ways for doing both. The appreciation expressed by students is significant considering that this collaboration was not pre-planned and incorporated in the course design. However, it was clear that the digital tools should only be chosen after the learning goals and objectives are determined. In this case study there was a convergence in the learning goals and objectives of the two courses and that made the Collector App appropriate for the courses. This case study also demonstrates how doing digital humanities can be small and limited but still produce results (Ives, 2014: 223). It also can be done simply by relying on resources the institution and students already have. The fact that American college students tend to be equipped with Smartphones makes using Apps much easier. Resources available to faculty at their home institutions, whether in the form of funding for course enhancement or staff willing to create websites and digital tools for courses, create many possibilities to experiment in digital humanities. As we demonstrated above, the collaboration between IUN and VCU was limited in scope and scale but it still proved beneficial to students who in the course survey registered an appreciation of how other regions in the United States remember through monuments and memorials. It was a new way of seeing and appreciating what has always been there. The students at Virginia Commonwealth University experienced a new digital tool and were able to compare with the tool they were already using. Moreover, this case study also demonstrated how future collaboration could be designed and implemented and how these partnerships do not require too much coordination and planning to be of benefit. This case study illustrates how digital humanities can be "more relevant" to the educational mission of public universities (Brier, 2012: 398; see also Waltzer, 2012: 344).

ILCEA, 39 | 2020 


\section{BIBLIOGRAPHY}

Althausen John D. \& MieCzKowsKi Thomas M. (2001), “The Merging of Criminology and Geography into a Course on Spatial Crime Analysis", Journal of Criminal Justice Education, 12, 367-383.

Alves Daniel \& QUEIROZ Ana (2015), "Exploring Literary Landscapes: From Texts to Spatiotemporal Analysis through Collaborative Work and GIS", International Journal of Humanities and Arts Computing, 9(1), 57-73.

BRIER Stephen (2012), "Where's the Pedagogy? The Role of Teaching and Learning in the Digital Humanities", M. K. Gold (ed.), Debates in the Digital Humanities, Minneapolis: University of Minnesota Press, 390-401.

Coulton Claudia (2005), "The Place of Community in Social Work Practice Research: Conceptual and Methodological Developments", Social Work Research, 29(2), 73-86.

DRENNON Christine (2006), “Teaching Geographic Information Systems in a Problem-Based Learning Environment", Journal of Geography in Higher Education, 29(3), 385-402.

FAGIN Todd \& WIKLE Thomas (2011), “The Instructor Element of GIS Instruction at US Colleges and Universities", Transactions in GIS, 15(1), 1-15.

FERRANDINO Joseph (2014), “Incorporating GIS as an Interdisciplinary Pedagogical Tool throughout an MPA Program", Journal of Public Affairs Education, 20(4), 529-544.

FERRANDINO Joseph (2015), “Using GIS to Apply Learning throughout the Undergraduate Criminal Justice Education", Journal of Criminal Justice Education, 26(1), 74-93.

FITCHеTt Paul \& Good Amy (2012), "Teaching Genocide through GIS: A Transformative Approach", Clearing House: A Journal of Educational Strategies, Issues and Ideas, 85(3), 87-92.

GosSARD Julia (2017), "Mapping the Early Modern World: Using Google Maps in the Classroom", online at Perspectives on History: <https://www.historians.org/publications-and-directories/ perspectives-on-history/october-2017/mapping-the-early-modern-world-using-google-maps-inthe-classroom> (October 2017).

HEPPLER Jason \& WOLFENSTEIN Gabriel (2015), “Crowdsourcing Digital Public History”, online at The American Historian: <https://tah.oah.org/content/crowdsourcing-digital-public-history/>.

HiLliER Amy (2007), “Why Social Work Needs Mapping”, Journal of Social Work Education, 43(2), 205221.

HIRSCH Brett (2014), “//Parentheses〉: Digital Humanities and the Place of Pedagogy”, B. Hirsch (ed.), Digital Humanities Pedagogy. Practices, Principles and Politics, Cambridge: Open Book Publishers, $3-30$.

IANTORNo Luke (2014), “Introducing Digital Humanities Pedagogy”, CEA Critic, 76, 140-146.

IVEs Maura (2014), "Digital Humanities Pedagogy: Hitting the Wall and Bouncing Back”, CEA Critic, $76,221-224$.

KNOWLES Anne (2008), “RUI: Holocaust Historical GIS”, online at Grantome: <http://grantome.com/ grant/NSF/BCS-0820501

MASON Susan (2008), "Client-Oriented Projects: GIS Course Design with the Potential to Service Multiple Constituents", Journal of Public Affairs Education, 14(2), 241-252. 
QUERALT Magaly \& WitTE Ann D. (1998), “A Map for You? Geographic Information Systems in the Social Services", Social Work, 43(5), 455.

READ Jane (2010), “Teaching Introductory Geographic Information Systems through ProblemBased Learning and Public Scholarship", Journal of Geography in Higher Education, 3, 379-399.

SHEPHERD Ifan (2009), "From Geography Department to Business School: Strategies for Transplanting GIS Courses between Disciplines", Journal of Geography in Higher Education, 33(1), S28-S45.

SINTON Diana \& LUND Jennifer (2006), Understanding Place: GIS and Mapping across the Curriculum, Redlands, California: ESRI Press.

SINTON Diana S. (2009), "Roles for GIS within Higher Education”, Journal of Geography in Higher Education, 33(S1), S7-S16.

SNYDER Jeffrey \& HAMmOND Thomas (2012), “'So That's What the Whiskey Rebellion Was!': Teaching Early US History with GIS”, The History Teacher, 45(3), 447-455.

Thomas Lindsay \& Solomon Dana (2014), “Active Users: Project Development and Digital Humanities Pedagogy", CEA Critic, 76, 211-220.

TREVEDI Bijal (2002), “Survey Reveals Geographic Illiteracy”, online at National Geographic: <https://news.nationalgeographic.com/news/2002/11/geography-survey-illiteracy/>.

WALTZER Luke (2012), “Digital Humanities and the ‘Ugly Stepchildren' of American Higher Education”, M. K. Gold (ed.), Debates in the Digital Humanities, Minneapolis, MN: University of Minnesota Press, 335-349.

WEIR Kimberley R. \& ROBERTSON John G. (1998), “Teaching Geographic Information Systems for Social Work Applications”, Journal of Social Work Education, 34(1), 81-96.

YIN Li (2010), "Integrating 3D Visualization and GIS in Planning Education", Journal of Geography in Higher Education, 34(3), 419-438.

YounG Christopher (2018), "Embracing the Digital Revolution in the History Classroom”, Teaching History: A Journal of Methods, 43, 2-16.

Young Christopher \& FERRANDINo Joseph (2018), “The Old Is New Again: Digital Mapping as an Avenue for Student Learning", online at EDUCAUSE Review: <https://er.educause.edu/articles/ 2018/10/the-old-is-new-again-digital-mapping-as-an-avenue-for-student-learning> (October 2018).

\section{APPENDIXES}

Appendix

Survey Questions

Q1: Do you believe that the Collector App mapping assignment contributed to your learning?

Q2: Please explain your answer to question one.

Q3: Do you think the Collector App could be useful for assignments in other courses? Q4: Can you imagine using the Collector App in your chosen profession after you graduate from College?

Q5: Do you think you will continue to use and contribute to the Collector App after this 
course?

Q6: Did you find the Collector App to be user/student friendly?

Q7: Please explain any frustrations that you experienced using the Collector App.

Questions added for the students at Virginia Commonwealth University in Richmond, Virginia, USA.

Q11: Did your perception of Richmond change as a result of this assignment involving the Collector App?

Q12: Did how you relate to Richmond as a city change as a result of this assignment involving the Collector App? ${ }^{1}$

\section{NOTES}

1. Questions 8, 9, and 10 asked students to compare their experience with the ArcGIS Collector and the ArcGIS computer version, both of which were used in the History class at Indiana University Northwest. Since this article focuses on the pedagogical uses of the Collector Application, the questions were eliminated from this document.

\section{ABSTRACTS}

Undergraduate research is a high impact practice for student learning, but the key is often to match projects with tools that build students' skills as they learn about a topic. Digital tools now profligate to the point that they are almost overwhelming to the student and teacher alike. These tools, coupled with computing have forged an entirely new field: digital humanities. Our manuscript discusses how one easy to use, student friendly digital tool-ARCGIS's mobile app, Collector-is used in collaborative undergraduate research. The tool's usefulness stems from its potential to contribute to the relationship between the discourse on digital humanities with its actual practice in the classroom. The Collector App encourages undergraduate researchers to go beyond the confines of the classroom and into the field to conduct research with one of their favorite tools, their smartphone. The Collector App allows past-present-and future classes of students to intermingle in a digital space that is devoted to creating knowledge for public use. The easy-to-use digital tool facilitates undergraduates in the Humanities and other disciplines to become cognizant of the world immediately around them in a new way while also equipping them with a technical skill that may be applied in other courses as well as in future employment scenarios. In short, the Collector App serves as a place where applied research and the scholarship of discovery intersect. As such, the Collector App contributes to the expansion of the digital humanities into undergraduate education. We present as evidence several different collaborative digital undergraduate projects that span classes and semesters and all involve primary field research through Collector. The Collector-based research projects have encouraged students to build skills while contributing to knowledge in new ways.

La recherche de premier cycle est une pratique à fort impact sur l'apprentissage des étudiants, mais la clé est souvent de trouver des outils qui renforcent les compétences des étudiants tout en apprenant sur un sujet donné. Les outils numériques sont maintenant si présents qu'ils sont 
presque écrasants tant pour les élèves que pour les enseignants. Ces outils, associés à l'informatique, ont forgé un tout nouveau domaine: les sciences humaines numériques. Notre manuscrit explique la façon dont un outil numérique facile à utiliser et convivial pour les étudiants - l'application mobile d'ARCGIS, Collector - est utilisé dans la recherche collaborative dans le premier cycle universitaire. L'utilité de l'outil découle de son potentiel à contribuer à la relation entre le discours sur les sciences humaines numériques et sa pratique réelle en classe. Le Collector App encourage les chercheurs de premier cycle à sortir des limites de la salle de classe et à se rendre sur le terrain pour mener des recherches avec l'un de leurs outils préférés, leur téléphone portable mobile. L'application Collector permet aux anciennes et futures classes d'élèves de se mêler dans un espace numérique dédié à la création de connaissances à usage public. Cet outil numérique facile à utiliser permet aux étudiants de premier cycle en sciences humaines et dans d'autres disciplines de se familiariser avec le monde qui les entoure immédiatement et de façon nouvelle tout en acquérant une compétence technique qui pourra être utilisée dans d'autres cours ainsi que dans de futurs scénarios professionnels. En résumé, l'application Collector sert de lieu d'intersection entre la recherche appliquée et la découverte scientifique. À ce titre, l'application Collector App contribue à l'expansion des sciences humaines numériques dans l'enseignement de premier cycle. Nous présentons comme preuve plusieurs projets de collaboration de premier cycle en numérique qui s'étendent sur plusieurs classes et semestres et qui impliquent tout une recherche primaire sur le terrain par le biais de Collector.

INDEX

Keywords: anthropology, collaboration, faculty, geographic information systems (GIS), high impact practices, history, mapping, mobile devices, monuments, student engagement, urban

Mots-clés: anthropologie, collaboration, systèmes d'information géographique (SIG), pratiques à impact élevé, histoire, cartographie, appareils mobiles, monuments, participation des étudiants, urbain

\section{AUTHORS}

CHRISTOPHER J. YOUNG

Indiana University Northwest, USA

JOSEPH A. FERRANDINO

Ferris State University, USA

FAEDAH M. TOTAH

Virginia Commonwealth University, USA 